\title{
The use of photogrammetry to evaluate chest wall after arthrodesis in patients with Adolescent Idiopathic Scoliosis
}

\author{
O uso da fotogrametria na avaliação da caixa torácica após \\ artrodese em pacientes com Escoliose Idiopática do Adolescente
}

\author{
Fabíola Pereira Rebouças ${ }^{[\mathrm{a}]}$, Evandro Fornias Sperandio ${ }^{[\mathrm{a}]}$, Anderson Salles Alexandre ${ }^{[\mathrm{a}]}$, \\ Liu Chiao $\mathrm{Yi}^{[\mathrm{a}]}$, Alberto Ofenhejm Gotfryd ${ }^{[\mathrm{b}]}$, Milena Carlos Vidotto ${ }^{[a]^{*}}$
}

[a] Universidade Federal de São Paulo (UNIFESP), São Paulo, SP, Brazil

[b] Hospital Israelita Albert Einstein (HIAE), São Paulo, SP, Brazil

\begin{abstract}
Introduction: Adolescent Idiopathic Scoliosis (AIS) is a three-dimensional spine deformity that creates changes in the rib cage biomechanics. Objective: Evaluate changes on the chest wall, quality of life and lung function on the preoperative and postoperative of arthrodesis in patients with AIS. Methods: Eighteen AIS patients with surgical indication for arthrodesis of both sexes aged between 11 and 18 years were evaluated. The evaluation of the chest was taken by using photogrammetry Postural Assessment Software (PAS). Thoracic markers were created using angles (A) and distances (D): A1 (bilateral acromion/manubrium), A2 (bilateral acromion/xiphoid process), A3 (bilateral rib/xiphoid process), A5 (acromion/scapula inferior angle/inframammilary), A6 (C7/acromion/T3), A7 (scapular irregularity) and D3 (xiphoid process to the anterior superior iliac spine). Spirometry and assessment of Quality of Life Questionnaire (SRS - 30) was performed. Evaluations were performed on the preoperative period (PRE), on two months of postoperative (PO1) and on the late postoperative period (LPO). Data were analysed using analysis of variance with repeated measures and Bonferroni method comparisons. Results: The
\end{abstract}

\footnotetext{
FPR: MS, e-mail: fpr_fisio@hotmail.com EFS: PhD, e-mail: evandrosperandio@yahoo.com ASA: MS, e-mail: andersales@hotmail.com LCY: PhD, e-mail: liuchiaoyi@yahoo.com.br AOG: PhD, e-mail: albertocoluna@yahoo.com.br MCV: PhD, e-mail: milenavidotto@hotmail.com
} 
thoracic markers A1, A2, A3, A5, A6, A7 and D3 showed significant difference in the LPO. All domains and the total score of the SRS - 30 questionnaire showed significant increase in periods P01 and LPO. The FVC and FEV1 showed significant increase in the LPO. Conclusion: After arthrodesis patients with AIS showed alterations in the chest wall, associated with improved quality of life and lung function, especially in the late postoperative period.

Keywords: Scoliosis. Thorax. Photogrammetry. Quality of Life. Postoperative Period.

\section{Resumo}

Introdução: A escoliose idiopática do adolescente (EIA) é uma deformidade tridimensional da coluna vertebral que gera alterações na biomecânica da caixa torácica. Objetivo: Avaliar as alterações da caixa torácica, a qualidade de vida e função pulmonar no pré e no pós-operatório de artrodese em pacientes com EIA. Métodos: Foram avaliados 18 pacientes com indicação cirúrgica para a correção de EIA de ambos os sexos com idade entre 11 e 18 anos. A avaliação da caixa torácica foi feita pela fotogrametria utilizando o Software de Avaliação Postural (SAPO). Foram criados marcadores torácicos em forma de ângulos (A) e distâncias (D): A1(acrômios bilateral/manúbrio), A2 (acrômios bilateral/processo xifoide), A3 (últimas costelas bilateral/processo xifoide), A5 (acrômio/ângulo inferior da escápula/inframamilar), A6 (C7/acrômio/T3), A7 (desnivelamento das escápulas) e D3 (processo xifoide-espinha ilíaca ântero-superior). Foi realizada a espirometria e avaliação do Questionário de Qualidade de Vida (SRS-30). Os pacientes foram avaliados no pré-operatório (PRE), pósoperatório de dois meses (PO1) e no pós-operatório tardio de um ano (POT). Foi realizada análise de variância com medidas repetidas e o método de comparações de Bonferroni. Resultados: Os marcadores torácicos A1, A2, A3, A5, A6, A7 e D3 apresentaram diferença significante no POT. Todos os domínios e a pontuação total do questionário SRS-30 apresentaram aumento significante nos períodos PO1 e POT. A e o VEF1 apresentaram aumento significante no POT. Conclusão: Após artrodese os pacientes com EIA apresentaram alterações na caixa torácica, associada com a melhora na qualidade de vida e função pulmonar, principalmente no pós-operatório tardio.

Palavras-chave: Escoliose. Tórax. Fotogrametria. Qualidade de Vida. Período Pós-Operatório.

\section{Introduction}

Scoliosis is a three-dimensional deformity of the elements of the spine [1]. Among scoliosis types, idiopathic scoliosis accounts for about $90 \%$ of all cases, and the most common is adolescent scoliosis, affecting females at a higher rate than males [2].

The Cobb method evaluates the intensity of the angular deformity of scoliosis, being the method most widely used for assessing the progression and severity of Adolescent Idiopathic Scoliosis (AIS) [3]. The value of the Cobb angle is directly proportional to the severity of scoliosis, and it is believed that the higher the angle value, the greater the spinal and thoracic deformity [4].

The spine and ribs act together as a dynamic and efficient biomechanical structure. In scoliosis, the anteroposterior and transverse diameters of each hemithorax differ significantly, and as a result there is asymmetric insufflation of the lungs. In addition, thoracic expansion is limited because the movement of the ribs is restricted, which reduces complacency of the thoracic wall [5].

Due to the involvement of the thoracic cavity, patients with AIS may present respiratory changes, such as pulmonary restriction and altered strength of respiratory muscles [6]. In addition to respiratory alterations, patients with AIS may present painful spinal complaints, low self-esteem, dissatisfaction with appearance, and reduced functional capacity to perform some activities of daily living, compromising quality of life [7].

Some cases of AIS cannot be controlled by conservative methods and corrective surgery is indicated [6]. Surgery is performed by means of arthrodesis that aims to realign the elements of the spine by decreasing the angular value of the curve. 
However, this intervention may trigger imbalance of the spine due to biomechanical change in trunk correction $[7,8]$.

On the other hand, since AIS patients present thoracic cavity distortions due to spinal deformity, it is expected that surgical correction may promote the reorganization of the chest structures, positively affecting the thoracic shape, respiratory variables and the quality of life of the patients submitted to this intervention.

To our knowledge, there are no studies that quantify in an objective way the thoracic alterations generated by the AIS and its evolution after the arthrodesis surgery. An interesting alternative may be digital photogrammetry, a non-invasive method, easy to apply, reliable reproducibility and without the harmful effects of X-ray ionizing radiation $[9,10]$.

Thus, the present study aim to evaluate chest changes, quality of life, angular changes of the spine, respiratory muscle strength and lung function in the pre- and postoperative arthrodesis in patients with AIS.

\section{Methods}

This was a longitudinal observational study in which patients with Adolescent Idiopathic Scoliosis were selected from the outpatient clinic of the Hospital Santa Casa da Misericórdia de Santos. Patients with a diagnosis of the disease were classified as Type I Lenke with deviation of the main thoracic curve to the right, of both genders, aged between 11 and 18 years and surgical indication. Patients with previous or current history of heart, lung or neuromuscular disease and patients who failed to perform the proposed evaluations were excluded.

Participants and their representatives signed the Term of Free and Informed Consent and the Term of Assentment. Both were approved by the Research Ethics Committee (CEP 1335/11) of the Federal University of São Paulo-Hospital São Paulo.

The patients were evaluated in three moments. In the preoperative period (PRE), in the postoperative period of two months (PO1) and in the late postoperative one year (LPO). The P01 assessment was performed on average 75 days after surgery and the LPO evaluation was performed on average 14 months after surgery.

The evaluation of angular changes in the spine was performed by the same senior evaluator in spine surgery at the Santa Casa da Misericórdia Hospital in Santos. This evaluation was also performed at the three moments (PRE, P01 and LPO) and allowed the performance and use of the radiographic examination of the spine, with the measurement of the Cobb angle, to follow the treatment of these patients. The angles of the proximal and main thoracic Cobb, the lumbar Cobb angle and the angles of the Cobb thoracic profile and the lumbar profile, were recorded using the Anterior-radiography and Profile (PA) of the teenagers's spine.

After the Cobb angle measurement, the curves were classified according to the criteria proposed by Lenke et al. [11]. Lenke's classification of the type I selected in this study is defined as the main thoracic curve structured with proximal and lumbar thoracic curves flexible and unstructured.

All the proposed evaluations were carried out by the same physiotherapists of the Research Group previously trained. All the patients were submitted to the initial evaluation, consisting of an anamnesis and physical examination. In the anamnesis, the patient was questioned about the current situation of the disease and associated diseases. On physical examination, vital signs such as Blood Pressure (BP), Heart Rate (HR) and body mass, height and Body Mass Index (BMI) were measured.

\section{Thoracic evaluation by photogrammetry}

The subjects remained in orthostatic position at a previously marked location, at a distance of $3.0 \mathrm{~m}$ from the camera. The digital camera (SONY-Cyber Shot, DCS-W300) was positioned parallel to the floor with the help of a professional tripod positioned at half height of the individual.

A plumb line was placed on the evaluation room's ceiling, marking one meter to calibrate the photos in an upright position. The photographs were taken in the anterior, left lateral, right lateral and posterior views. Participants were asked to wear bathing suits to allow the markers to be displayed.

A Vinyl Acetate (EVA) carpet was used so that the foot position was marked and rotated at each shooting while the camera and tripod remained in the same position. 
The anatomical points were marked on the skin by the fixation of a half ball of Styrofoam balls, using double-sided adhesive tape, in the orthostatic posture, always by the same experienced and trained evaluator to perform the palpations. The marked anatomic points that were based on the PAS protocol were: acromion of the bilateral scapula; bilateral anterosuperior iliac spine; $\mathrm{C} 7$ spinous process; upper angle of the bilateral scapula; T3 spinous process; and lower angle of the bilateral scapula. The anatomic point marked on the sternum's manubrium was based on the study of Davidson et al. [10] located at the upper margin of the manubrium at the midpoint between the two sternoclavicular joints. The anatomical points created by our team were: xiphoid process of the sternum (located with the palpation of the lower edge of the last ribs towards the medial region of the thorax, in the encounter of the last ribs, in the so-called Sharp angle); (located in the middle of the distance by drawing a straight line descending to the body between the nipple and the last rib of this region) and last bilateral false rib (located in the straight descending line perpendicular to the nipples, at the crossing point of the last rib of this region) Figure 1.

The photos were analyzed through the Postural Assessment Software (PAS), validated by Ferreira et al. [12], always by the same experienced evaluator in the handling of the program and obeyed the following steps: photo aperture, 75\% zoom, image calibration, analysis of the linear and angular measurements between the anatomical points previously demarcated, using as reference the center of the marker.

We assessed thoracic markers (A) and distances (D) created by our team, with the exception of angle A1 that was reproduced from the study of Davidson et al. [10]. The thoracic markers evaluated were: A1 (right acromion/manubrium/left acromion), A2 (right acromion/xiphoid/left acromion), A3 (last false right rib/xiphoid/last false left rib), A4 (angle formed from the deepest point of the waist and its upper and lower edges bilateral), A5 (inframamilar/inferior angle of the scapula/right and left acromion), A6 (C7/ right and left acromion/T3), A7 (angle formed by the intersection of the tangent segments of the upper and lower scapulae angles), D1 (xiphoid-last false rib on the right and left sides), D2 (manubrium-last false rib on the right and left sides) and D3 (xiphoid-anterior superior iliac spine on the left and right sides), as illustrated in Figures 1 and 2.

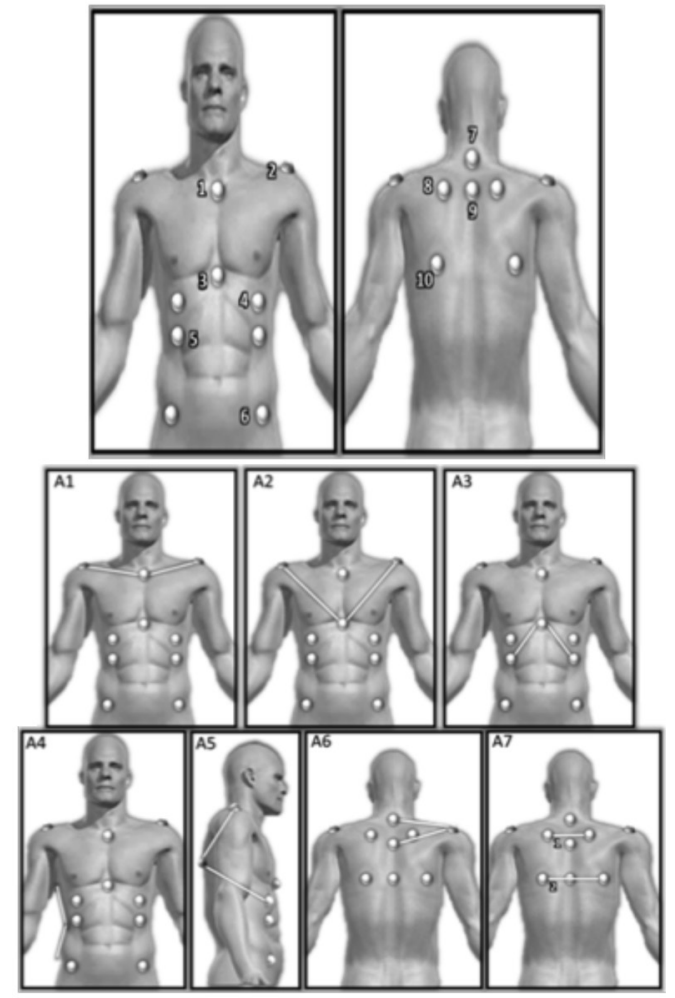

Figure 1 - 1. Manubrium of sternum; 2. Acromion of the scapula; 3. Xiphoid process of sternum; 4. Inframammary region (half the distance between nipple and last false rib); 5.Last false rib (intersection of nipple line with last false rib); 6.Antero-superior iliac spine (ASIS); 7. C7 spiny process; 8. Upper angle of the scapula; 9.T3 thymus proces; 10. Lower angle of scapula. Al. Right (R) acromion/manubrium/left (L) acromion; A2. R acromion/xiphoid process/L acromion; A3. R Last false rib/xiphoid process/L last false rib; A4. Side deviation of the trunk; A5. Acromion/lower angle of scapula/ inframammary; A6. C7/acromion/T3; A7. Intersection of segments 1 and 2 .

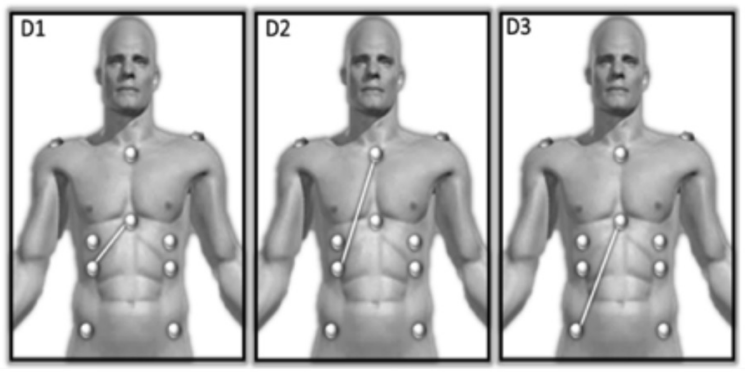

Figure 2 - D1. Xiphoid process/last false rib; D2. Manubrion/ last false rib; D3. Xiphoid process/Antero-superior iliac spine.

With the exception of A4, all other angles and distances created were marked using anatomical points. As the A4 marker was measured from the 
deepest point and the upper and lower waist edges, its measurement ends up being influenced by the subjectivity of the evaluator. Although the analysis was always done by the same individual, but considering the possibility of the reproduction of this angle by other evaluators, we used the tool "edge detector", available in the software PAS, to facilitate the visualization of the body margins, in order to accurate and reliable analysis.

Quality of life assessment

Quality of life was assessed using a specific questionnaire for patients with AIS, the Scoliosis Research Society-30 (SRS-30). The 30 questions of the questionnaire were read to the patient as well as all possible answers, asking him to choose only one answer. Study participants responded to the test within approximately five minutes without any difficulties.

\section{Respiratory evaluation}

Respiratory muscle strength was assessed by maximal Inspiratory (PI max) and Expiratory Pressure (PE max) measurements according to the recommendations of the Brazilian Society of Pulmonology and Tisiology [13]. A manovacuometer (WIKA CI1.6, Critical Med) was used with the participant sitting.

Measurements of PImax and PEmax were performed from Functional Residual Capacity [FRC], with occlusion of the unidirectional valve of the manovacuometer and with a nasal obturator. In both cases, the measurements were repeated three times or until the last measurement was smaller than the previous one. The largest of the three measurements was considered for data analysis.

Spirometry was performed using a spirometer (Spiropalm; Cosmed, Pavona di Albano, Italy) and was based on the recommendations of the Brazilian Society of Pneumology and Tisiology (SBPT, 2002) [13]. FVC, FEV1, and FEV1/FVC ratio were quantified in absolute values and in percentages of predicted values for the Brazilian population, adapted for the appropriate gender and age group [13].

\section{Statistical method}

The sample size was calculated using the value of the main thoracic Cobb angle (based on our inclusion criterion) as the response variable. We considered as the initial information the clinically significant minimum difference between the PRE and P01 periods of $20^{\circ}$ and the difference between the PRE and LPO periods of $30^{\circ}$ [14]. When a power of more than 0.90 was defined as a significance level of 0.05 , the minimum sample size was 11 patients.

Descriptive analysis was expressed as mean (standard deviation) for numerical variables and percentages for categorical variables. To compare the behavior of the variables in the evaluated periods, the model of analysis of variance with repeated measurements (ANOVA) and the multiple comparisons method of Bonferroni. The data were analyzed by statistical program $\mathrm{R}$, version 2.15.1. The probability of alpha error was set at $5 \%$ for all analyzes.

\section{Results}

We initially evaluated 25 patients with a surgical indication for arthrodesis for the correction of AIS, seven of them were excluded (28\%), one for the diagnosis of asthma and the other for not being classified as type I Lenke and for not having a thoracic curve with right shift. Thus, in the preoperative period (PRE), 18 patients were evaluated. Of these, 13 returned to the postoperative evaluation of two months (P01) and 11 returned for a one-year postoperative evaluation (LPO). The 11 patients included in the study had a mean age of $15 \pm 2.2$ years, nine $(82 \%)$ were females, mean height of $1.60 \pm 0.09$ meters, mean body mass of $46.5 \pm 8,5 \mathrm{~kg}$, mean BMI of $18.2 \pm 3.1 \mathrm{~kg} / \mathrm{m}^{2}$.

The thoracic markers that presented difference between the evaluated periods were A1, A2, A3, A5 right (R) side, A6 R and left (L) sides, A7 and D3 R, as shown in Table 1. 
Table 1 - Comparison of the means of the angles and thoracic distances in the Preoperative (PRE), Postoperative (POI) and late Postoperative (LPO) periods of the 11 patients evaluated

\begin{tabular}{|c|c|c|c|}
\hline $\begin{array}{c}\text { Angles and } \\
\text { thoracic distances }\end{array}$ & Periods & Mean (SD) & $\mathrm{p}$ \\
\hline \multirow[t]{3}{*}{ A1 } & PRE-P01 & $173.3(8.5)-172.4(9.6)$ & 0.11 \\
\hline & PRE-LPO & 173.3(8.5)-166.2(9.4) & $<0.01$ \\
\hline & P01-LP0 & $172.4(9.6)-166.2(9.4)$ & 0.44 \\
\hline \multirow[t]{3}{*}{ A2 } & PRE-P01 & $90.9(7.9)-89.3(9.5)$ & 0.99 \\
\hline & PRE-LPO & $90.9(7.9)-82.6(10.9)$ & 0.01 \\
\hline & P01-LP0 & 89.3(9.5)-82.6(10.9) & 0.03 \\
\hline \multirow[t]{3}{*}{ A3 } & PRE-P01 & $91.3(14.9)-86.5(15.8)$ & 0.48 \\
\hline & PRE-LPO & $91.3(14.9)-110(19.1)$ & $<0.01$ \\
\hline & P01-LP0 & $86.5(15.8)-110(19.1)$ & $<0.01$ \\
\hline \multirow[t]{3}{*}{ A5R } & PRE-P01 & $74.4(9.9)-80.3(6.5)$ & 0.01 \\
\hline & PRE-LPO & $74.4(9.9)-78.3(7.8)$ & 0.03 \\
\hline & P01-LP0 & $80.3(6.5)-78.3(7.8)$ & 0.99 \\
\hline \multirow[t]{4}{*}{ A6R } & PRE-P01 & $15.9(4.5)-17.8(3.6)$ & 0.17 \\
\hline & PRE-LPO & $15.9(4.5)-20.6(4.4)$ & $<0.01$ \\
\hline & P01-LP0 & $17.8(3.6)-20.6(4.4)$ & 0.64 \\
\hline & PRE-P01 & 16.1(3.9)-17.1(3.4) & 0.99 \\
\hline \multirow[t]{3}{*}{ A6L } & PRE-LPO & $16.1(3.9)-18.4(6.7)$ & 0.05 \\
\hline & P01-LP0 & $17.1(3.4)-18.4(6.7)$ & 0.15 \\
\hline & PRE-P01 & $6.7(4.5)-4.4(3.0)$ & 0.31 \\
\hline \multirow[t]{3}{*}{ A7 } & PRE-LPO & $6.7(4.5)-2.2(1.8)$ & $<0.01$ \\
\hline & P01-LP0 & $4.4(3.0)-2.2(1.8)$ & 0.33 \\
\hline & PRE-P01 & $22.7(3.4)-25.6(2.1)$ & $<0.01$ \\
\hline \multirow[t]{2}{*}{ D3R } & PRE-LPO & $22.7(3.4)-24.7(1.7)$ & 0.06 \\
\hline & P01-LP0 & $25.6(2.1)-24.7(1.7)$ & 0.99 \\
\hline
\end{tabular}

Note: SD - standard deviation; $p$ - level of significance; $A 1$ - right acromion/manubrium/left acromion; A2 - right acromion/xiphoid process/left acromion; A3 - last false right rib/xiphoid process/ last false left rib; A5R - acromion/lower angle of scapula/right inframammary; $A 6 \mathrm{R}$ and $\mathrm{L}-\mathrm{C}$ /acromion/T3 right and left sides; $A 7$ - angle formed by the intersection of the tangent segments of the upper and lower scapulae angles; D3R - right anterosuperior iliac spine-xiphoid process.

All domains of the SRS-30 quality of life questionnaire and also their total score showed increase in the PO1 and LPO periods compared to the PRE, as shown in Table 2.
Table 2 - Comparison of the values of the domains and total score of the SRS-30 quality of life questionnaire in the Preoperative (PRE), Postoperative (POI) and late Postoperative (LPO) periods of the 11 patients evaluate

\begin{tabular}{lccc}
\hline \multicolumn{1}{c}{ SRS-30 } & Periods & Mean (SD) & $\mathbf{p}$ \\
\hline Function & PRE-P01 & $18.9(4.3)-25.8(4.9)$ & $<0.01$ \\
& PRE-LPO & $18.9(4.3)-26.9(3.8)$ & $<0.01$ \\
\multirow{5}{*}{ Pain } & P01-LPO & $25.8(4.9)-26.9(3.8)$ & 0.99 \\
& PRE-P01 & $19.4(4.4)-24.8(4.7)$ & $<0.01$ \\
& PRE-LPO & $19.4(4.4)-25.2(3.9)$ & $<0.01$ \\
Image & P01-LPO & $24.8(4.7)-25.2(3.9)$ & 0.99 \\
& PRE-P01 & $18.1(4.4)-36.9(4.4)$ & $<0.01$ \\
& PRE-LPO & $18.1(4.4)-36.1(5.2)$ & $<0.01$ \\
Mental Health & P01-LPO & $36.9(4.4)-36.1(5.2)$ & 0.99 \\
& PRE-P01 & $17.4(3.8)-19.8(4.3)$ & $<0.01$ \\
& PRE-LPO & $17.4(3.8)-21.4(3.2)$ & $<0.01$ \\
Satisfaction & P01-LPO & $19.8(4.3)-21.4(3.2)$ & 0.99 \\
& PRE-P01 & $7.38(2.5)-14.1(1.4)$ & $<0.01$ \\
& PRE-LPO & $7.38(2.5)-13.8(1.3)$ & $<0.01$ \\
& P01-LPO & $14.1(1.4)-13.8(1.3)$ & 0.99 \\
& PRE-P01 & $81.1(12.7)-121.6(14.6)$ & $<0.01$ \\
Total & PRE-LPO & $81.1(12.7)-124.0(12.6)$ & $<0.01$ \\
& P01-LPO & $121.6(14.6)-124.0(12.6)$ & 0.99 \\
\hline
\end{tabular}

Note: SD - standard deviation; p - level of significance.

The mean Cobb angles of the patients included in the study were: proximal thoracic Cobb $24.7 \pm 9.1$, main thoracic $60.5 \pm 11.5$, lumbar $36.3 \pm 10$, thoracic profile $21.2 \pm 10.8$ and lumbar profile $43.6 \pm 9.1$.

The averages of the proximal thoracic Cobb, main thoracic Cobb and lumbar Cobb angles presented reduction in $\mathrm{PO} 1$ and $\mathrm{LPO}$ in relation to PRE ( $p<0.01)$. The Cobb angle of the thoracic profile showed an increase in LPO when compared to the PRE (Table 3).

FVC showed a significant increase in LPO when compared to PRE and when compared to P01. FEV1 also showed a significant increase in LPO when compared to PRE. The maximum respiratory pressures did not present a significant difference in the periods evaluated (Table 3). 
Table 3 - Comparison of Cobb angles and respiratory variables in the Preoperative (PRE), Postoperative (POI) and Late Postoperative (LPO) periods of the 11 patients evaluated

\begin{tabular}{|c|c|c|c|}
\hline $\begin{array}{c}\text { Cobb Angles } \\
\text { (Degrees) }\end{array}$ & Periods & Mean (SD) & $\mathrm{p}$ \\
\hline \multicolumn{4}{|l|}{ Proximal Thoracic } \\
\hline & PRE-P01 & 24.7(9.1)-16.3(9.4) & $<0.01$ \\
\hline & PRE-LPO & $24.7(9.1)-12.3(6.5)$ & $<0.01$ \\
\hline & P01-LP0 & $16.3(9.4)-12.3(6.5)$ & 0.99 \\
\hline \multirow[t]{3}{*}{ Thoracic Mean } & PRE-P01 & $60.5(11.5)-20.6(11.6)$ & $<0.01$ \\
\hline & PRE-LPO & $60.5(11.5)-17.9(9.5)$ & $<0.01$ \\
\hline & P01-LP0 & $20.6(11.6)-17.9(9.5)$ & 0.99 \\
\hline \multirow[t]{3}{*}{ Lumbar } & PRE-P01 & $36.3(10.1)-15.4(9.1)$ & $<0.01$ \\
\hline & PRE-LPO & $36.3(10.1)-15.0(9.5)$ & $<0.01$ \\
\hline & P01-LPO & $15.4(9.1)-15.0(9.5)$ & 0.99 \\
\hline \multirow[t]{3}{*}{ Profile Thoracic } & PRE-P01 & $21.2(10.8)-26.2(6.2)$ & 0.22 \\
\hline & PRE-LPO & $21.2(10.8)-30.6(13.4)$ & 0.04 \\
\hline & P01-LP0 & 26.2(6.2)-30.6(13.4) & 0.99 \\
\hline \multicolumn{4}{|l|}{$\begin{array}{l}\text { Espirometric } \\
\text { Variables }\end{array}$} \\
\hline \multirow[t]{3}{*}{$\mathrm{FVC} \mathrm{(L)}$} & PRE-P01 & $2.53(0.62)-2.46(0.56)$ & 0.99 \\
\hline & PRE-LPO & $2.53(0.62)-2.85(0.67)$ & $<0.01$ \\
\hline & P01-LPO & $2.46(0.56)-2.85(0.67)$ & $<0.01$ \\
\hline \multirow[t]{3}{*}{ FVE1 (L) } & PRE-P01 & $2.17(0.63)-2.23(0.47)$ & 0.99 \\
\hline & PRE-LPO & $2.17(0.63)-2.62(0.43)$ & $<0.01$ \\
\hline & P01-LPO & $2.23(0.47)-2.62(0.43)$ & 0.14 \\
\hline \multirow[t]{3}{*}{ FVC\% } & PRE-P01 & $80.9(13.9)-76.7(16.3)$ & 0.99 \\
\hline & PRE-LPO & $80.9(13.9)-84.5(15.5)$ & 0.31 \\
\hline & P01-LPO & $76.7(16.3)-84.5(15.5)$ & 0.31 \\
\hline \multirow[t]{3}{*}{ FEV1\% } & PRE-P01 & $74.5(21.9)-74.5(15.8)$ & 0.99 \\
\hline & PRE-LPO & $74.5(21.9)-85.4(12.1)$ & 0.22 \\
\hline & P01-LPO & $74.5(15.8)-85.4(12.1)$ & 0.22 \\
\hline \multirow[t]{3}{*}{ PImax $\left(\mathrm{cmH}_{2} \mathrm{O}\right)$} & PRE-P01 & $74.1(29.2)-72.3(25.2)$ & 0.99 \\
\hline & PRE-LPO & $74.1(29.2)-80.9(19.2)$ & 0.33 \\
\hline & P01-LP0 & 72.3(25.2)-80.9(19.2) & 0.33 \\
\hline \multirow[t]{3}{*}{ PEmax $\left(\mathrm{cmH}_{2} \mathrm{O}\right)$} & PRE-P01 & $78.8(40.1)-73.1(28.1)$ & 0.69 \\
\hline & PRE-LPO & $78.8(40.1)-73.6(19.6)$ & 0.69 \\
\hline & P01-LP0 & $73.1(28.1)-73.6(19.6)$ & 0.99 \\
\hline
\end{tabular}

Note: FVC - forced vital capacity; FVC\% - percentage of predicted FVC value; FEV 1 - forced expiratory volume in the first second; FEV1\% - percentage of predicted FEV1; PImax - maximal inspiratory pressure; PEmax - maximum expiratory pressure; SD - standard deviation; $p$ - level of significance.

\section{Discussion}

The present study evaluated thoracic cavity changes, quality of life, angular changes of the spine and respiratory variables in the pre- and postoperative period of arthrodesis in patients with AIS. It was observed that after surgical intervention the thoracic markers A1, A2, A3, A5D, A6D and A7 and D3D presented significant alterations, showing important changes in the shape of the rib cage. We also observed an improvement in the quality of life, the pulmonary function and the decrease in spinal changes.

The thoracic markers A1, A2 and A3 presented significant alterations in the late postoperative period when compared to the preoperative period. We believe that this may be a reflection of the surgical correction, since the spinal rotations caused by the scoliosis form the ribs, turning them back and forth on the convex side, and forward on the concave side $[14,15]$. It is possible that these changes directly reflect a better alignment of the sternum and the ribs after the surgical correction. More aligned ribs favor pulmonary mechanics and the movement of the rib cage, improving pulmonary function. This fact could be observed in our study, as we also found improvement of pulmonary function in the late postoperative period of AIS correction.

The A5D angle showed a significant increase in the postoperative period of two months and late in relation to the preoperative period, we suggest that this increase may reflect the reduction of thoracic kyphosis after correction of thoracic vertebral curvature.

The A6D and E angles showed a significant increase in the late postoperative period in relation to the preoperative period, we suggest with this finding that the surgical correction provided better alignment of the shoulders. We also suggested better alignment of the shoulder blades in the late postoperative period, demonstrated by the decrease in the A7 angle when compared to the preoperative period. According to the Brazilian Society of Orthopedics and Traumatology (SBOT), patients with AIS classified as Lenke I, with a shift of the main thoracic curve to the right, present the right upper and lower left scapula, therefore, we can suggest that the A7 marker was able to detect characteristic unevenness of the scapulae in these patients and their correction in the postoperative period. 
The D3D thoracic marker presented a significant increase in the postoperative period of two months, when compared to the preoperative period. We suggest with this finding short-term improvement of pelvic imbalance in these patients after arthrodesis.

Most of the alterations found in the thoracic markers were in the late postoperative period, we believe that this happened because most of the compensations generated by scoliosis are structured, requiring a longer period for its reorganization after the surgical correction.

In our study, we observed a positive impact of surgical correction on the quality of life of patients with AIS. All values of the domains and the total score of the SRS-30 questionnaire presented an increase in the postoperative period, when compared to the preoperative period.

It is known that alterations in the vertebral column, in addition to compromising the body biomechanics, also interfere in the individuals' quality of life. Several studies [16-18] have shown that problems related to the spine can significantly affect the quality of life related to health and negatively interfere in the wellbeing of individuals with spinal changes.

Spinal pain is an important complaint in the AIS [19]. In our study, we observed improvement of the pain domain both in the postoperative period of two months and in the late postoperative period. This result was similar to the study by Asher et al. [20], which demonstrated improvement of the pain domain followed by improvement of self-image, a result that also corroborates with our study. In addition to the positive impact on the quality of life of the adolescents, the surgical correction generated changes in the Cobb angle. The surgical correction of the AIS produces significant changes in the Cobb angles, avoiding the progression of the spine deformity, with the improvement of the trunk balance in the coronal and sagittal planes, avoiding possible cardiorespiratory complications [20].

In the present study, we observed a significant reduction of angles of the main, proximal and Cobb lumbar Cobb in the postoperative period of two months and late when compared with the preoperative one. These results are corroborated by Canavese et al. [21], Lima Jr et al. [22] and Gotfryd et al. [23], allowing us to state that the surgery has successfully minimized spinal alterations.

In our study, we observed an increase in FVC and FEV1 in the late postoperative period compared to the preoperative period. Studies have disagreed about the effects of surgical correction on lung function in patients with scoliosis. Robinson et al. [24] demonstrated reduced lung capacity after surgery. Chong et al. [25] demonstrated reduced FVC and did not observe changes in FEV 1 after three and six postoperative years. Smiljanic et al. [26] also did not find postoperative pulmonary function change.

Probably the results are very divergent due to the different characteristics of the populations studied, differences in age, sex, type of curve, type of surgery and time of evaluation in the postoperative period. We believe that we found improvement in lung function in the late postoperative period in our study, mainly because our population was more homogeneous because it presented only the main thoracic curve (Lenke type I).

As the thoracic curvatures are the ones that most influence pulmonary function, we believe that their correction also influences it positively. In addition, studies that showed a reduction in lung function had longer postoperative follow-up, different from our study where the mean of the late postoperative period was 14 months.

One limitation of our study is that the PAS method evaluates photographs in only two dimensions. Taking into account the three-dimensional behavior of scoliotic posture, it is likely that the PAS method, even though it is a reproducible method [12, 27-30], is not the most adequate method to evaluate changes in scoliosis. However, we used the method to evaluate the effects of the surgical procedure on the chest cavity format and not to quantify the deformity caused by scoliosis. Thus, we observed important alterations in the thoracic cavity, especially in the late postoperative period, along with reduced spinal angulations, improvement in lung function and quality of life.

\section{Conclusion}

We can conclude that after performing the arthrodesis for the correction of AIS, the patients presented important modifications in the rib cage, showing a better alignment between the ribs and sternum and improvement in the quality of life, especially in the late postoperative period, besides alterations in the spine, with Cobb angle decrease, and improvement in lung function. 


\section{References}

1. Hattori T, Sakaura H, Iwasaki M, Nagamoto $Y$, Yoshikawa H, Sugamoto K. In vivo theree-dimensional segmental analysis of adolescent idiopathic scoliosis. Eur Spine J. 2011;20(10):1745-50.

2. Arlet V, Reddi V. Adolescent Idiopathic Scoliosis. Neurosurg Clin N Am. 2007;18(2):255-9.

3. Ali RM, Boachie-Adjei O, Rawlins BA. Functional and radiographic outcomes after surgery for adult scoliosis using third-generation instrumentation techniques. Spine (Phila Pa 1976). 2003;28(11):11639; discussion 1169-70.

4. Canavese F, Turcot K, Holveck J, Farhoumand AD, Kaelin A. Changes of concave and convex rib-vertebral angle, angle difference and angle ratio in patients with right thoracic adolescent idiopathic scoliosis. Eur Spine J. 2011;20(1):129-34.

5. Redding GJ, Praud JP, Mayer OH. Pulmonary function testing in children with restrictive chest wall disorders. Pediatr Allergy Immunol Pulmonol. 2011;24(2):89-94.

6. Ferreira F, Pugin OT, Guimarães EA, Cardoso GM, Makhoul CMB, Dutra Filho AD, et al. Função pulmonar em paciente com escoliose. Conscientiae Saúde. 2009;8(1):123-7.

7. Haher TR ${ }^{1}$, Gorup JM, Shin TM, Homel P, Merola AA, Grogan DP, et al. Results of the Scoliosis Research Society Instrument for evaluation of surgical outcomes in adolescent idiopathic scoliosis. A multicenter study of 244 patients. Spine (Phila $\mathrm{Pa}$ 1976). 1999;24(14):1435-40.

8. Avanzi O, Landim E, Meves R, Caffaro MFS, Umeta RSG. Escoliose idiopática do adolescente: correlação entre parâmetros radiográficos de correção e resultado clínico de tratamento. Coluna/Columna. 2008;7(3):201-8.

9. Souza JA, Pasinato F, Basso D, Corrêa ECR, Silva AMT. Biofotogrametria: confiabilidade das medidas do protocolo do software para avaliação postural (SAPO). Rev Bras Cineantropom Desempenho Hum. 2011;13(4):299-305.
10. Davidson J, Santos AM, Garcia KM, Yi LC, João PC, Miyoshi $\mathrm{MH}$, et al. Photogrammetry: an accurate and reliable tool to detect thoracic musculoskeletal abnormalities in preterm infants. Physiotherapy. 2012;98(3):243-9.

11. Lenke LG, Betz RR, Harms J, Bridwell KH, Clements $\mathrm{DH}$, Lowe TG, et al. Adolescent idiopathic scoliosis: a new classification to determine extent of spinal arthrodesis. J Bone Joint Surg Am. 2001;83-A(8):1169-81.

12. Ferreira EAG, Duarte M, Maldonado EP, Burke TN, Marques AP. Postural assessment software (PAS/SAPO): validation and reliabiliy. Clinics. 2010;65(7):675-81.

13. Mallozi MC. Valores de referência para espirometria em crianças e adolescentes, calculados a partir de uma amostra da cidade de São Paulo [dissertation]. São Paulo: Universidade Federal de São Paulo; 1995. 121 p. Valores finais publicados em: Pereira CAC, editor. I Consenso Brasileiro sobre Espirometria. J Pneumol. 1996;22(3):105-64.

14. Gotfryd AO, Franzin FJ, Poletto PR, Laura AS, Silva LCF. Radiografias em inclinação lateral como fator preditivo da correção cirúrgica na escoliose idiopática do adolescente. Rev Bras Ortop. 2011;46(5):572-6.

15. Bonato C, Amaral GR, Johnston C, Einloft P. Ventilação não-invasiva com pressão positiva (VNIPP) e insuficiência respiratória aguda no pós-operatório de escoliose idiopática: relato de caso. Scientia Medica. 2005;15(4):243-8.

16. Asher M, Min Lai S, Burton D, Manna B. The reliability and concurrent validity of the scoliosis research society-22 patient questionnaire for idiopathic scoliosis. Spine (Phila $\mathrm{Pa}$ 1976). 2003;28(1):63-9.

17. Lai SM, Asher M, Burton D. Estimating SRS-22 quality of life measures with SF-36: application in idiopathic scoliosis. Spine (Phila Pa 1976). 2006;31(4):473-8. 
18. Rosanova GCL, Gabriel BS, Camarini PMF, Gianini PES, Coelho DM, Oliveira AS. Validade concorrente da versão brasileira do SRS-22r com o Br-SF-36. Rev Bras Fisioter. 2010;14(2):121-6.

19. Andersen MO, Christensen SB, Thomsen K. Outcome at 10 years after treatment for adolescent idiopathic scoliosis. Spine (Phila Pa 1976). 2006;31(3):350-4.

20. Asher MA, Min Lai S, Burton DC. Further development and validation of the Scoliosis Research Society (SRS) outcomes instrument. Spine (Phila Pa 1976). 2000;25(18):2381-6.

21. Canavese F, Gupta S, Krajbich JI, Emara KM. Vacuumassisted closure for deep infection after spinal instrumentation for scoliosis. J Bone Joint Surg Br. 2008;90(3):377-81.

22. Lima Jr PC, Pellegrino L, Caffaro MFS, Meves R, Landim E, Avanzi O. Escoliose Idiopática do Adolescente (EIA): perfil clínico e radiológico da lista de espera para tratamento cirúrgico em hospital terciário de alta complexidade do sistema público de saúde brasileiro. Coluna/Columna. 2011;10(2):111-5.

23. Gotfryd A0, Franzin FJ, Raucci G, Carneiro Neto NJ, Poletto PR. Tratamento cirúrgico da escoliose idiopática do adolescente utilizando parafusos pediculares: análise dos resultados clínicos e radiográficos. Coluna/Columna. 2011;10(2):91-6.

24. Bettany-Saltikov J, Warren JG, Robinson J. Limits of normality and symmetry in standing back shape and posture. Scoliosis. 2010;5(Suppl 1):05.
25. Chong HS, Moon ES, Kim HS, Ankur N, Park JO, Kim JY, et al. Comparison between Operated Muscular Dystrophy and Spinal Muscular Atrophy Patients in terms of Radiological, Pulmonary and Functional Outcomes. Asian Spine J. 2010;4(2):82-8.

26. Smiljanić I, Kovac V, Cimić M. Changes in pulmonary function parameters after surgical treatment of idiopathic scoliosis. Coll Antropol. 2009;33(Suppl 2):145-52.

27. Ribeiro AP, Trombini-Souza F, Iunes DH, MonteRaso VV. Confiabilidade inter e intra-examinador da fotopodometria e intra-examinador da fotopodoscopia. Rev Bras Fisioter. 2006;10(4):435-9.

28. Döhnert MB, Tomasi E. Validade da fotogrametria computadorizada na detecção de escoliose idiopática adolescente. Rev Bras Fisioter. 2008;12(4):290-7.

29. Braz RG, Goes FPDC, Carvalho GA. Confiabilidade e validade de medidas angulares por meio do software para avaliação postural. Fisioter Mov. 2008;21(3):117-26.

30. Iunes DH, Castro FA, Salgado HS, Moura IC, Oliveira AS, Bevilaqua-Grossi D. Confiabilidade intra e interexaminadores e repetibilidade da avaliação postural pela fotogrametria. Rev Bras Fisioter. 2005;9(3):327-34.

Received on $06 / 29 / 2016$

Recebido em 29/06/2016

Approved on 09/18/2017

Aprovado em 18/09/2017 